\title{
SOCIAL ANTECEDENTS OF ENTREPRENEURIAL ORIENTATION - PROSOCIAL MOTIVATION AND ORGANIZATIONAL CITIZENSHIP BEHAVIOR
}

Przemysław Zbierowski

University of Economics in Katowice

e-mail: przemyslaw.zbierowski@ue.katowice.pl

\begin{abstract}
Purpose: The purpose of the paper is to investigate the combined effect of prosocial motivation and organizational citizenship behavior on entrepreneurial orientation
\end{abstract}

Methodology/approach: The research was carried out on a sample of 406 enterprises using multisource cross-sectional design. The main analytical technique is hierarchical regression analysis.

Findings: No impact of prosocial motivation on innovativeness was observed. Among dimensions of OCB only three of them proved to have any impact on organizational entrepreneurship. Altruism is positively related to innovativeness and proactiveness. Sportsmanship is positively related to all three dimensions of entrepreneurial orientation. The only negative influence of OCB dimensions on organizational entrepreneurship was observed for conscientiousness and innovativeness. Environment seems to have a strong impact on the relationship between OCB and entrepreneurial orientation. Expectedly, the impact of dynamism and complexity is positive, so in fast changing and complicated circumstances that influence is stronger. Unexpectedly, for environmental hostility the effect is negative.

Implications/limitations either for further research, for practice, or for society: The study brings some practical recommendations concerning the ways of making the company more entrepreneurial concerning altruism, sportsmanship and conscientiousness. The results also add to ongoing discussion on dimensionality of entrepreneurial orientation. As the impact of prosocial motivation and OCB is rather similar for all three dimensions of EO, results point to rather unidimensional view of entrepreneurial orientation instead of multidimensional one.

Originality/value of the paper: The study brings some contribution to the discussion on social antecedents of entrepreneurial orientation. It sheds light on possible outcomes of organizational citizenship behaviors for organizational entrepreneurship. Until now, the research in that regard was rather scarce.

Keywords: entrepreneurial orientation, prosocial motivation, organizational citizenship behavior

Paper type: Research paper 
SOCIAL

ANTECEDENTS OF ENTREPRENEURIAL

Przemysław Zbierowski

\section{Introduction}

Organizational entrepreneurship has been recently one of the most intensively explored topics in management science. It is associated with high organizational effectiveness and other desired outcomes. Therefore, the scholarly investigation explores the ways of enhancing organizational entrepreneurship. One of its most widely accepted conceptualizations and operationalizations is entrepreneurial orientation, most commonly constructed with three dimensions (innovativeness, proactiveness and risk taking). In this paper I ask a question of possible influence on entrepreneurial orientation from 'social' attitudes and behaviors of employees, namely prosocial motivation and organizational citizenship behavior. Those two constructs are heavily researched within positive organizational scholarship, but their impact on organizational entrepreneurship has not been fully researched so far. Therefore, the purpose of the paper is to investigate the combined effect of prosocial motivation and organizational citizenship behavior on entrepreneurial orientation. Therefore, I ask if companies where employees are motivated by possible contribution to others people's lives and where they are organizational citizens achieve higher level of organizational entrepreneurship. Additionally, I argue that that relationship is strongly contextual and heavily dependent on the shape of task environment: its dynamism, hostility and complexity. The study therefore has potential to uncover complex relationships between social antecedents of organizational entrepreneurship in various contextual circumstances. The research was carried out within research project 2014/13/B/ HS4/01618 funded by National Science Centre, Poland.

\section{Entrepreneurial orientation}

The base assumption for entrepreneurial orientation scale is that entrepreneurial firms differ from other types of firms. They tend to take more risk than other types of firms, proactively search for new business opportunities and have strong emphasis on new product innovation (Khandwalla, 1977; Miller and Friesen, 1982; Mintzberg, 1973). Some researchers operationalized the behavior of entrepreneurial firms as consisting of product-market innovation, proactiveness of decision making, and risk-taking. They maintained that the level of entrepreneurship presented by a firm was the aggregate total of these three sub-dimensions: "the extent to which top managers are inclined to take business-related risks (the risk-taking dimension), to favor change and innovation in order to obtain a competitive advantage for their firm (the innovative dimension), and to compete aggressively with other firms (the proactive dimension)" (Covin and Slevin, 1988) These scholars also argued that a firm that was truly entrepreneurial should exhibit high levels of each dimension.

The most widely used operationalization of entrepreneurial orientation construct comes from Covin and Slevin (1989), based on Khandwalla (1977) and Miller and Friesen (1982). They stated that innovativeness, proactiveness 
and risk-taking act together creating uni-dimensional strategic orientation, and should be aggregated together. This assumption and the operationalization itself proved reliable and valid in many studies, however, later works raised concern pertaining to the dimensionality of the measure and the independence of the sub-dimensions (Dess et al., 1999; Lumpkin and Dess, 1996; Zahra, 1993). As opposite to unidimensional measure as constructed by Covin and Slevin (1989) multi-dimensional measure reflecting each of the sub-dimensions was proposed (e.g. Lumpkin and Dess, 1996). Proponents of later approach argued that each sub-dimension of entrepreneurial orientation construct uniquely contributes to entrepreneurial process. They highlight the potential of each sub-dimension to have a different impact for key outcome variables such as firm performance (Lumpkin and Dess, 2001).

Another important issue concerning entrepreneurial orientation is its validity for research in different countries. Formerly used constructs were developed originally for studies in the United States and then utilized for research in international entrepreneurship without adequately examining their validity. Steensma, Marino, Weaver, and Dickson (2000) found that contemporary management theories may not be applicable in all international research contexts due to differences in national culture. Following this concern Kreiser, Marino, and Weaver (2002) employed a multi-country sample to explore the cross-cultural validity of a entrepreneurial orientation construct. Their study provided strong support for the cross-cultural validity of this scale. It has to be stressed that entrepreneurial orientation concerns behaviors and not attitudes of the business, which is also reflected in measures.

\section{Organizational citizenship behavior}

Organizational citizenship behavior (OCB) also called prosocial work behavior are "behaviors aimed at providing help or benefit to others" (Cameron et al., 2003). The essential part of this kind of behaviors is exceeding standard work roles and expectations and being grounded in altruistic assumptions on intrinsic need to help other person, although the authentic motivation for OCB is still a matter of scholarly discussion. Daniel Organ (1998), who is considered to be the founder of organizational citizenship behavior, presents its frames and components. According to him OCBs are "behaviors of discretionary nature that are not part of formal requirements presented to employees, but nevertheless contributing to effective functioning of the organization" (1988). Organizational citizenship behaviors go beyond the work role but have organizational consequences. It is however important to differentiate OCB from organizational prosocial behaviors that are aimed at improving the well-being of an individual, group or organization (Brief and Motowidlo, 1986) but might be not related to the organization itself. 
SOCIAL

ANTECEDENTS OF ENTREPRENEURIAL

Przemysław Zbierowski
Organ (1988) highlights three important aspects of organizational citizenship behaviors: (1) they are not formally recognized by remuneration system, are not a part of job description, are performed in fully discretionary manner based on employee's personal choice, (2) they go beyond what can be coerced from the employees based on their job description, (3) they positively contribute to the performance of other employees, and consequently to the performance of the whole organization. There is an ongoing debate on the degree of discretionarity of OCB. Some scholars claim that they might not be as altruistic as expected and part of the motivation might be related to expected reciprocity according to social exchange theory. Also the assumption of exceeding the job description is criticized. Organ himself (1997) decided to revise that assumption due to the development of organizational procedures towards creating more general job roles instead of detailed and specific job descriptions. Organ (1988) also presents five-dimensional model of organizational citizenship behavior with following dimensions: (1) Altruism - discretionary behaviors that aim and which result in helping other person in performing organizationally important task or solving organizationally important problem. Altruistic behaviors might be limited to internal organizational context, but may also go beyond organizational borders and be directed at the outside world. (2) Conscientiousness - discretionary employee behaviors which go beyond minimal requirements of the job description. They may relate to lack of absenteeism, obeying the rules, brakes at work etc. (3) Civic virtue - behaviors that indicate the deep concern of the employee of the organizational life and his or her active involvement. They also include positive identification with problems of the organization. (4) Courtesy - discretionary behaviors directed at preventing conflicts with other members of the organization. It is a helping behavior that aim is to prevent the occurrence of problems. It also encompasses civility, good manners and politeness. (5) Sportsmanship - willingness of the employee to tolerate the conditions of work that are worse than ideal without complaining and exaggerating problems. Organizational citizenship behaviors, as the name suggests, are behavioral in nature, which is reflected in their measures.

\section{Prosocial motivation}

Prosocial motivation very well reflects the intellectual tradition of positive streams: positive psychology and positive organizational scholarship. It is enriched with thinking in terms of interpersonal relations. Positive approach to motivation entitles that the purpose of action is another human being, in particular the improvement of her or his life. That person could be on the inside or outside of the organization or it might even be a group of people. In some cases the recipients might not be known to the prosocially motivated person, although the personalization is rather important. 
Prosocial motivation is defined as "the desire to protect or improve the well-being of other people" (Grant and Berg, 2012). As the definition suggests, prosocial motivation is of volitional nature, it could be qualified as 'attitude' based on personality and values. It should be distinguished from altruism that has been described as a part of organizational citizenship behaviors. Prosocial motivation can take various forms that are described by Batson, Ahmad, Powell and Stocks (2008). They state that motivation is composed of four components: altruistic, egoistic, principal and collective. Grant and Berg (2012) argue that prosocial motivation can exist in any configuration of the above. It can present altruistic purposes when it protects and builds the well-being of other people, egoistic purposes when it raises positive affect and self-esteem and reduces negative affect and brings material benefits, principal purposes when it raises moral and ethical value and collective purposes when it protects of strengthens the attachment of the individual to the group.

The position of prosocial motivation on the continuum of intrinsic and extrinsic motivation raises an important question. Most of the scholars agree that it can have both the intrinsic and extrinsic nature, however, it is more significant when intrinsic component dominates the extrinsic one (Gebauer et al., 2008; Grant and Berg, 2012). Moreover, it can be places at any level in the framework where general motivation is a trait and refers to general, stable in time attitude of an employee towards goals and actions in various time and various situations, contextual motivation refers to specific category of behaviors and can vary to some extend in time depending on the circumstances and situational motivation refers to willingness to act in particular case, in specific time and is highly dynamic (Vallerand, 1997). General prosocial motivation refers to tendency of an employee to contribute to the well-being of others in general sense. It can guide the choice of occupation that will allow to perform activities that bring positive consequences in other peoples' lives. Contextual prosocial motivation refers to contributing to the well-being of the specific group of people or specific individuals through performing specific job. Situational prosocial motivation refers to contributing to well-being of others in specific situation, through performing specific task.

At the situational level it is highly probable that the conflict arises between prosocial motivation and self-interest. That conflict is an area of debate between scholars that claim that prosocial motivation and self-interest are mutually exclusive and those that state that they can be reconciled or at least may coexist. That conflict is very likely to be resolved at the contextual and general levels which is caused by the possibility to select in the long run activities that benefit others and those that benefit the employee.

Prosocial motivation also includes three primary components and motivation proposed by psychologists: direction, intensity and persistence of the effort (Kanfer, 1990). Employees can be prosocially motivated in the direction of contributing to

SOCIAL
ANTECEDENTS OF ENTREPRENEURIAL

Przemysław Zbierowski 
SOCIAL

ANTECEDENTS OF ENTREPRENEURIAL

Przemysław Zbierowski physical (health and safety), developmental (learning and growth), psychological (happiness and joy) and material (financial and economic status) well-being of other people, groups or bigger social structures such as organizations, nations or even the whole humanity (Grant, 2007). As said before, prosocial motivation might be directed both to the inside and outside of the organization.

Prosocial motivation might vary in terms of intensity, and the more intensive, the more it will be guided by affective instead of cognitive system. Persistence of prosocial motivation strongly depends on the need of other person or group of people that is directed towards. If the need is of immediate and temporary nature than prosocial motivation will disperse after the need is satisfied. On the other end of the continuum there are needs that are permanent that can guide long-term prosocial motivation on general level.

The main stream of prosocial motivation research refers to when, how and why experiences, emotions and behaviors of employees are fueled by the care for contributing to others' well-being. Other important topic of scientific considerations are the consequences of prosocial motivation in various contexts. The research shows for instance that prosocial motivation can lead employees to take initiative, help others, persistence in performing task important for an employee and accepting the negative feedback. For instance Grant (2008) proves that call-center employees of charities are able to attract from 171\% to even $406 \%$ more donations when they are exposed to direct contact with final beneficiaries of the donations. Prosocial motivation can be also successfully measured. The fiveitem scale to do so was presented by Grant and Sumanth (2009).

\section{Hypotheses development}

Unfortunately, the literature does not provide a lot of arguments for supporting organizational entrepreneurship by organizational citizenship behaviors. Those two concepts are however linked for instance by Luu (2017) who proves that organizational entrepreneurship moderates the relationship between corporate social responsibility and OCB. Moreover, Zhang, Wan and Jia (2008) claim that OCB mediate the relationship between high performance work practices (HPWP) and entrepreneurship and organizational level. Yan and Yan (2013) state on other hand that organizational engagement has positive impact on innovations. Above arguments lead to formulating the hypothesis:

\section{H1. Organizational citizenship behaviors positively influence organizational} entrepreneurship.

Prosocial motivation is mainly linked with social entrepreneurship. Leaving aside arguments in this domain there is some evidence that prosocial motivation supports entrepreneurship more generally and even at the organizational level. Lebel and Patil (2018) based on theory of motivated information processing prove that prosocial motivation can result in high levels of proactiveness even when it 
is negatively perceived by the superiors. Prosocial motivation can also weaken negative relationship between perceived discouraging behavior of the supervisor and proactiveness by driving employees to introduce change influencing coworkers in the organization. Because they are less focused on self-interest and more on benefitting others, prosocially motivated employees have ability to maintain the responsibility for change and effectiveness in proactiveness.

Also Grant and Berry (2011) based on research carried out on a sample of 90 officers prove that intrinsically motivated employees create ideas that are not only novel but also useful, which results in high creativity (Amabile et al., 2005). that relationship is additionally moderated by prosocial motivation that strengthens the impact of intrinsic motivation on creativity. Employees who manifest only high intrinsic motivation have a tendency to create novelty that is not always useful. Highly prosocially motivated employees are additionally driven by the willingness to create value for customers that makes their ideas more useful. All of the above arguments allow to formulate the hypothesis:

H2. Prosocial motivation positively influences organizational entrepreneurship.

Additionally, there are arguments that above relationships might be under the influence of the shape of task environment. Zahra (1993) analyzing the relationship between organizational entrepreneurship and financial performance points out to three dimensions of task environment potentially influencing that relationship: dynamism, hostility and complexity. That view is corroborated by Dess and Beard (1984), Miller (1987) and Sharfman and Dean (1991). Dynamism is reflected by "unpredictability of behaviors of customers and competitors, rate of change of market trends, innovations, research and development" (Miller, 1987), hostility is "the degree of competitions, its dimensions and legal limitations" (Miller, 1987), and complexity is "heterogeneity and range of organization's activities" (Dess and Beard, 1984). There is fragmented evidence that the consequences of some variables under research are dependent on the shape of the environment. For instance it concerns courtesy (Porath et al., 2010). More generally Stankiewicz (2010) and Glińska-Neweś (2010) point to environment as the moderator between positive variables and their consequences, therefor I hypothesize:

H3. Task environment moderates the relationships between organizational citizenship behaviors, prosocial motivation and organizational entrepreneurship in a way that in dynamic, hostile and complex environments those relationships are stronger.

\section{Method. Research design, sample, variables and measures, analytical techniques}

The research was carried out in cross-sectional design on a random sample of 406 enterprises. The research was carried out using the technique of personal interview

SOCIAL
ANTECEDENTS OF ENTREPRENEURIAL

Przemysław Zbierowski 
SOCIAL

ANTECEDENTS OF ENTREPRENEURIAL

Przemysław Zbierowski
(CAPI). In each enterprise two people were surveyed: senior manager (ownermanager or member of the board if possible) and the direct subordinate of that person. Sampling was random and the sample frame was the database of Polish enterprises employing from 50 to 1000 employees. The choice to exclude small and very large enterprises was caused by the nature of researched relationships. A couple of industries were excluded from the sampling: section A (PKD - Polish Classification of Activity) - farming, forestry, hunting and fishing, section B Mining and extraction of natural resources, section E - water supply, sewage and waste management, recultivation, section $\mathrm{O}$ - public administration, national defense, obligatory social security, section $\mathrm{Q}$ - healthcare and social support, section $\mathrm{T}$ - households employing workers, households producing goods and serving services for their own needs, section $\mathrm{U}$ - exterritorial organizations and groups. Organizations in those sections run a specific activities that could distort the research results.

The independent variables in my model are: entrepreneurial orientation, prosocial motivation and organizational citizenship behaviors. Moderators are dynamism, hostility and complexity of environment. Dependent variable is entrepreneurial orientation with its dimensions: innovativeness, proactiveness and risk taking. To measure organizational citizenship behaviors the scale developed by Podsakoff, MacKenzie, Moorman and Fetter (1990) was used. Three items measure altruism (0.839), four items measure conscientiousness (0.859), four items measure civic virtue (0.834), four items measure courtesy $(0.789)$ and four items measure sportsmanship (0.836). Prosocial motivation was measured using the Grant and Sumanth (2009) scale with three items separately for managers (0.862) and employees (0.879). Entrepreneurial orientation was measured using Kreiser, Marino and Weaver (2002) scale with three dimensions: innovativeness (three items, 0.842), proactiveness (three items, 0.834), risk taking (two items, 0.833). For entrepreneurial orientation and organizational citizenship behaviors the confirmatory factor analysis has been conducted that confirmed the dimensionality of the constructs.

The main analytical technique used was hierarchical regression analysis. For each of the dimensions as a dependent variable three regression models were tested. In model 1 only control variables very taken into consideration as independent variables, in model 2 both control variables and independent variables (prosocial motivation, OCB) were tested, in model 3 they were supplemented with environment variables. It is important to note that in regression models the joint effect of prosocial motivation and organizational citizenship behaviors is tested. The separate effect of those constructs has been tested as robustness check. 
7. Results

Table 1 presents the results of analysis of correlation between prosocial motivation, OCB and dimensions of entrepreneurial orientation.

\begin{tabular}{|c|c|c|c|c|}
\hline & & $\begin{array}{l}\text { Entrepreneurial } \\
\text { orientation: } \\
\text { innovativeness }\end{array}$ & $\begin{array}{l}\text { Entrepreneurial } \\
\text { orientation: } \\
\text { proactiveness }\end{array}$ & $\begin{array}{l}\text { Entrepreneurial } \\
\text { orientation: } \\
\text { risk taking }\end{array}$ \\
\hline \multirow{3}{*}{$\begin{array}{l}\text { Leader's } \\
\text { prosocial } \\
\text { motivation }\end{array}$} & Pearson's correlation & $0.305^{* *}$ & $0.290^{* *}$ & $0.187^{* * *}$ \\
\hline & Significance & 0.000 & 0.000 & 0.000 \\
\hline & $\mathrm{N}$ & 406 & 406 & 406 \\
\hline \multirow{3}{*}{$\begin{array}{l}\text { Follower's } \\
\text { prosocial } \\
\text { motivation }\end{array}$} & Pearson's correlation & $0.283^{* *}$ & $0.263^{* *}$ & $0.196^{* *}$ \\
\hline & Significance & 0.000 & 0.000 & 0.000 \\
\hline & $\mathrm{N}$ & 406 & 406 & 406 \\
\hline \multirow{3}{*}{$\begin{array}{l}\text { OCB: altru- } \\
\text { ism }\end{array}$} & Pearson's correlation & $0.361^{* *}$ & $0.377^{* * *}$ & $0.263^{* * *}$ \\
\hline & Significance & 0.000 & 0.000 & 0.000 \\
\hline & $\mathrm{N}$ & 406 & 406 & 406 \\
\hline \multirow{3}{*}{$\begin{array}{l}\text { OCB: con- } \\
\text { scientiousness }\end{array}$} & Pearson's correlation & $0.226^{* *}$ & $0.297^{* *}$ & $0.265^{* *}$ \\
\hline & Significance & 0.000 & 0.000 & 0.000 \\
\hline & $\mathrm{N}$ & 406 & 406 & 406 \\
\hline \multirow{3}{*}{$\begin{array}{l}\text { OCB: sport- } \\
\text { smanship }\end{array}$} & Pearson's correlation & $0.159^{* *}$ & $0.124^{*}$ & $0.107^{*}$ \\
\hline & Significance & 0.001 & 0.012 & 0.031 \\
\hline & $\mathrm{N}$ & 406 & 406 & 406 \\
\hline \multirow{3}{*}{$\begin{array}{l}\text { OCB: cour- } \\
\text { tesy }\end{array}$} & Pearson's correlation & $0.290^{* * *}$ & $0.341^{* *}$ & $0.267^{* * *}$ \\
\hline & Significance & 0.000 & 0.000 & 0.000 \\
\hline & $\mathrm{N}$ & 406 & 406 & 406 \\
\hline \multirow{3}{*}{$\begin{array}{l}\text { OCB: civic } \\
\text { virtue }\end{array}$} & Pearson's correlation & $0.335^{* *}$ & $0.329^{* * *}$ & $0.251^{* * *}$ \\
\hline & Significance & 0.000 & 0.000 & 0.000 \\
\hline & $\mathrm{N}$ & 406 & 406 & 406 \\
\hline
\end{tabular}

High correlation coefficients between some of the variables suggest some multicollinearity issues. That problem has been tested using Variance Inflation Factor (VIF). The results of that test point to some low to moderate multicollinearity, especially between dimensions of organizational citizenship behaviors (more specifically altruism, courtesy and civic virtue). The highest observed values of VIF slightly exceeded the value of 4.0. This issue is a known problem when testing the combined effect of dimensions of one construct, and taking into consideration the level of value of 4.0 factor it can be accepted, especially that two of three dimensions with highest VIF levels (courtesy and civic virtue) are not predictors in any of the models.
SOCIAL

ANTECEDENTS OF ENTREPRENEURIAL

Przemysław Zbierowski

Table 1. Correlation matrix 
SOCIAL

ANTECEDENTS OF ENTREPRENEURIAL

Przemysław Zbierowski

Table 2. Regression models with innovativeness as dependent variable
The results of correlation analysis indicate that there are strong relationships between prosocial motivation, OCB and dimensions of entrepreneurial orientation. However, to test the hypotheses the regression analyses have to be performed. Their results are presented in tables 2-4.

\begin{tabular}{|c|c|c|c|}
\hline \multicolumn{4}{|c|}{ Innovativeness } \\
\hline & Model 1 & Model 2 & Model 3 \\
\hline \multirow{2}{*}{ Stable } & 2.499 & -0.530 & -1.687 \\
\hline & 0.000 & 0.340 & 0.003 \\
\hline \multirow{2}{*}{ Natural logarithm of age } & 0.284 & .235 & 0.159 \\
\hline & $0.007 * *$ & $.017 * *$ & 0.080 \\
\hline \multirow{2}{*}{ Natural logarithm of size } & 0.212 & 0.196 & 0.216 \\
\hline & $0.002 * *$ & $0.003 * *$ & $0.000 * *$ \\
\hline \multirow{2}{*}{ Prosocial motivation of the leader } & & 0.045 & 0.035 \\
\hline & & 0.660 & 0.708 \\
\hline \multirow{2}{*}{ Prosocial motivation of the followers } & & 0.068 & 0.082 \\
\hline & & 0.397 & 0.268 \\
\hline \multirow{2}{*}{ OCB - altruism } & & 0.364 & 0.305 \\
\hline & & $0.003 * *$ & $0.006^{* *}$ \\
\hline \multirow{2}{*}{ OCB - conscientiousness } & & -0.121 & -0.226 \\
\hline & & 0.248 & $0.020 *$ \\
\hline \multirow{2}{*}{ OCB - sportsmanship } & & 0.058 & 0.151 \\
\hline & & 0.261 & $0.003 * *$ \\
\hline \multirow{2}{*}{ OCB - courtesy } & & -0.038 & -0.040 \\
\hline & & 0.801 & 0.775 \\
\hline \multirow{2}{*}{ OCB - civic virtue } & & 0.245 & 0.188 \\
\hline & & 0.061 & 0.118 \\
\hline \multirow{2}{*}{ Environment: dynamism } & & & 0.416 \\
\hline & & & $0.000 * *$ \\
\hline \multirow{2}{*}{ Environment: hostility } & & & -0.225 \\
\hline & & & $0.002 * *$ \\
\hline \multirow{2}{*}{ Environment: complexity } & & & 0.239 \\
\hline & & & $0.000 * *$ \\
\hline $\mathrm{R}^{2}$ & 0.050 & 0.194 & 0.324 \\
\hline Adj. $\mathrm{R}^{2}$ & 0.046 & 0.176 & 0.303 \\
\hline
\end{tabular}

Regression models for innovativeness and dependent variable yield interesting results. First of all, there is a positive influence of age and size on innovativeness. Secondly, there is no impact of prosocial motivation. There is however, influence of some of the dimensions of OCB: positive effect of altruism and sportsmanship (only if environment is considered) and negative effect of conscientiousness 
(again, only if environment is considered). Finally, there is strong moderation by the shape of the environment: positive for dynamism and complexity and negative for hostility.

\begin{tabular}{|c|c|c|c|}
\hline \multicolumn{4}{|c|}{ Proactiveness } \\
\hline & Model 1 & Model 2 & Model 3 \\
\hline \multirow{2}{*}{ Stable } & 2.706 & -0.257 & -10.697 \\
\hline & 0.000 & 0.609 & 0.001 \\
\hline \multirow{2}{*}{ Natural logarithm of age } & 0.234 & 0.191 & 0.140 \\
\hline & $0.014 *$ & $0.032 *$ & 0.091 \\
\hline \multirow{2}{*}{ Natural logarithm of size } & 0.191 & 0.192 & 0.214 \\
\hline & $0.002 * *$ & $0.001 * *$ & $0.000 * *$ \\
\hline \multirow{2}{*}{ Prosocial motivation of the leader } & & -0.012 & -0.008 \\
\hline & & 0.898 & 0.923 \\
\hline \multirow{2}{*}{ Prosocial motivation of the followers } & & 0.040 & 0.052 \\
\hline & & 0.581 & 0.435 \\
\hline \multirow{2}{*}{ OCB - altruism } & & 0.321 & 0.276 \\
\hline & & $0.004 * *$ & $0.007 * *$ \\
\hline \multirow{2}{*}{ OCB - conscientiousness } & & 0.039 & -0.054 \\
\hline & & 0.677 & 0.542 \\
\hline \multirow{2}{*}{ OCB - sportsmanship } & & 0.028 & 0.132 \\
\hline & & 0.549 & $0.004 * *$ \\
\hline \multirow{2}{*}{ OCB - courtesy } & & 0.140 & 0.130 \\
\hline & & 0.308 & 0.308 \\
\hline \multirow{2}{*}{ OCB - civic virtue } & & 0.033 & -0.021 \\
\hline & & 0.780 & 0.847 \\
\hline \multirow{2}{*}{ Environment: dynamism } & & & 0.305 \\
\hline & & & $0.000 * *$ \\
\hline \multirow{2}{*}{ Environment: hostility } & & & -0.057 \\
\hline & & & 0.385 \\
\hline \multirow{2}{*}{ Environment: complexity } & & & 0.187 \\
\hline & & & $0.001 * *$ \\
\hline $\mathrm{R}^{2}$ & 0.046 & 0.192 & 0.316 \\
\hline Adj. $R^{2}$ & 0.041 & 0.174 & 0.295 \\
\hline
\end{tabular}

For proactiveness as dependent variable the results are somehow similar to regression models with innovativeness and dependent variable. There is a positive impact of age and size of the business, no influence of prosocial motivation was observed, among dimensions of OCB altruism and sportsmanship have a positive impact. Similarly to previous analysis, environmental dynamism and complexity have positive moderating effect and there is no effect of hostility.
SOCIAL ANTECEDENTS OF ENTREPRENEURIAL

Przemysław Zbierowski

\section{Table 3. Regression models with proactiveness as dependent variable}


SOCIAL

ANTECEDENTS OF

ENTREPRENEURIAL

Przemysław Zbierowski

Table 4. Regression models with risk taking as dependent variable

\begin{tabular}{|c|c|c|c|}
\hline \multicolumn{4}{|c|}{ Risk taking } \\
\hline & Model 1 & Model 2 & Model 3 \\
\hline \multirow{2}{*}{ Stable } & 3.029 & 0.740 & -0.134 \\
\hline & 0.000 & 0.162 & 0.809 \\
\hline \multirow{2}{*}{ Natural logarithm of age } & 0.184 & 0.168 & 0.099 \\
\hline & 0.057 & 0.074 & 0.260 \\
\hline \multirow{2}{*}{ Natural logarithm of size } & 0.168 & 0.173 & 0.189 \\
\hline & $0.008 * *$ & $0.005 * *$ & $0.001 * *$ \\
\hline \multirow{2}{*}{ Prosocial motivation of the leader } & & -0.094 & -0.109 \\
\hline & & 0.335 & 0.235 \\
\hline \multirow{2}{*}{ Prosocial motivation of the followers } & & 0.056 & 0.066 \\
\hline & & 0.461 & 0.351 \\
\hline \multirow{2}{*}{ OCB - altruism } & & 0.125 & 0.070 \\
\hline & & 0.280 & 0.513 \\
\hline \multirow{2}{*}{ OCB - conscientiousness } & & 0.168 & 0.076 \\
\hline & & 0.092 & 0.417 \\
\hline \multirow{2}{*}{ OCB - sportsmanship } & & 0.049 & 0.119 \\
\hline & & 0.315 & $0.016^{*}$ \\
\hline \multirow{2}{*}{ OCB - courtesy } & & 0.139 & 0.146 \\
\hline & & 0.337 & 0.280 \\
\hline \multirow{2}{*}{ OCB - civic virtue } & & 0.018 & -0.033 \\
\hline & & 0.886 & 0.775 \\
\hline \multirow{2}{*}{ Environment: dynamism } & & & 0.355 \\
\hline & & & $0.000 * *$ \\
\hline \multirow{2}{*}{ Environment: hostility } & & & -0.242 \\
\hline & & & $0.001 * *$ \\
\hline \multirow{2}{*}{ Environment: complexity } & & & 0.247 \\
\hline & & & $0.000 * *$ \\
\hline $\mathrm{R}^{2}$ & 0.032 & 0.120 & 0.243 \\
\hline Adj. $\mathrm{R}^{2}$ & 0.027 & 0.100 & 0.220 \\
\hline
\end{tabular}

For risk taking as dependent variable the results are slightly different to other two dimensions of EO. What is similar is a positive influence of size of the business, positive moderating effect of dynamism and complexity and negative of hostility and lack of influence of prosocial motivation. Among dimensions of OCB only sportsmanship is positively related to risk taking. All of the above results provide support for hypotheses $\mathrm{H} 1$ and $\mathrm{H} 3$ but do not provide support for hypothesis $\mathrm{H} 2$. 


\section{Robustness checks}

Reconfirm the results of regression analyses I have performed three robustness checks: reversed causality check, test of regression analysis with separate constructs (prosocial motivation and organizational citizenship behavior) as predictors and sample split check. For reversed causality check I performed regression analysis with each of the independent variables from main analyses (prosocial motivation of the leader, prosocial motivation of the follower, dimensions of organizational citizenship behaviors: altruism, conscientiousness, sportsmanship, courtesy, civic virtue). The values for $\mathrm{R}^{2}$ and adjusted $\mathrm{R}^{2}$ are presented in Table 5 .

\begin{tabular}{lcc}
\hline Model & R2 & Adj. R2 \\
\hline Prosocial motivation of the leader & 0.109 & 0.102 \\
\hline Prosocial motivation of the follower & 0.086 & 0.079 \\
\hline OCB.altruism & 0.159 & 0.152 \\
\hline OCB.conscientiousness & 0.093 & 0.086 \\
\hline OCB.sportsmanship & 0.025 & 0.018 \\
\hline OCB.courtesy & 0.118 & 0.111 \\
\hline OCB.civic virtue & 0.125 & 0.118 \\
\hline
\end{tabular}

The levels of adjusted $\mathrm{R}^{2}$ of reversed regression are lower than for main regression models, therefore it can be concluded that there is no reversed causality.

Second, I performed the regression analyses with separate constructs (prosocial motivation and OCB) as predictors. The levels of adjusted $\mathrm{R}^{2}$ for analyses with prosocial motivation as predictor are: 0.264, 0.257, 0.201, respectively for innovativeness, proactiveness and risk taking as dependent variables. The levels of adjusted $\mathrm{R}^{2}$ for analyses with $\mathrm{OCB}$ as predictor are $0.304,0.297,0.221$, respectively for innovativeness, proactiveness and risk taking as dependent variables. The levels of adjusted $\mathrm{R}^{2}$ confirm that the effect of organizational citizenship behavior on entrepreneurial orientation is much stronger than that of prosocial motivation.

Another robustness check that I performed was a random sample split and testing the regression models again. The results did not statistically differ from the regression models performed on entire researched sample.

\section{Discussion}

There are some interesting results that can be drawn from the study. First of all, there is a positive impact of size of the organization for all of dimensions of entrepreneurial orientation. This means that bigger companies are more entrepreneurial. Moreover, there is a positive impact of age of the organization on
SOCIAL ANTECEDENTS OF ENTREPRENEURIAL

Przemysław Zbierowski

Table 5. Results of reversed causality test 
SOCIAL

ANTECEDENTS OF ENTREPRENEURIAL

Przemysław Zbierowski two dimensions: innovativeness and proactiveness. However, age of the company is closely linked with size. The explanation for those relationships might be the higher level of resources that can be allocated for organizational entrepreneurship by bigger organizations. Smaller companies have to rely more on following the market leaders. It has to be taken into consideration that only medium and big companies were represented in the sample.

The study has not provided support for hypothesis $\mathrm{H} 2$ - no impact of prosocial motivation on innovativeness was observed. That result can be interpreted in two ways. The sample consisted of only commercial enterprises, no social entrepreneurs were taken into consideration. Perhaps the results would be completely different for social enterprises as prosocial motivation might be a good driver of innovation in such entities. Secondly, only direct relationships were tested in regression analyses. It is possible that prosocial motivation has an impact on organizational entrepreneurship, however, it might be indirect and some other variables might mediate it, such as creativity or meaning of work, or even OCB that is tested in the model as independent variable, but might be as well a mediating variable.

Among dimensions of OCB only three of them proved to have any impact on organizational entrepreneurship. Altruism is positively related to innovativeness and proactiveness. The possible explanation is the help that employees are able to get from their peers which helps them to be innovative and proactive. Altruistic climate allows more knowledge and experience exchange that in turns allows employees to use intellectual resources of other employees and create new solutions that results in higher innovativeness and proactiveness. That also relates to sportsmanship that is positively related to all three dimensions of entrepreneurial orientation. It is the ability to fully function within limited resources and be content. Employees can be therefore entrepreneurial even though conditions of their work are not ideal. Instead of complaining they can achieve their full potential and provide ideas for new solutions.

The only negative influence of OCB dimensions on organizational entrepreneurship was observed for conscientiousness and innovativeness. Intuitively thinking that relationship was expected as obeying formal requirements can result in lower creativity and innovativeness in the same way that conscientiousness as a trait of personality might limit the personal creativity of an individual.

Finally, environment seems to have a strong impact on the relationship between OCB and entrepreneurial orientation. Expectedly, the impact of dynamism and complexity is positive, so in fast changing and complicated circumstances that influence is stronger. Unexpectedly, for environmental hostility the effect is negative. It means that higher entrepreneurial orientation is achieved in munificent environments than in hostile ones. It is consistent with prior research (Zbierowski, 
2012) and might mean that in hostile environments Polish companies prefer to

apply secure strategies and limit their innovativeness, proactiveness and risk taking.

\section{Practical recommendations, contribution, limitations and future research}

The study brings some practical recommendations concerning the ways of making the company more entrepreneurial. First of all, altruism is a good way of supporting innovativeness and proactiveness. However, altruism seems to be strongly personality-based trait and there is a question if it might be management on organizational level. I argue that there are ways to create more altruistic approach of employees. For instance, Cameron (2008) presents useful ways of facilitating the transfer of positive energy, for example by fostering gratitude, forgiveness and compassion. Those kind of interventions are used with success by many companies. Similarly, promoting sportsmanship could be a good way to foster entrepreneurial orientation. That can be achieved through closer integration of employees with their organization and employees among themselves. The key is to treat employees seriously and expect the same from them. Concerning conscientiousness, slightly different approach is recommended. Instead of maximizing it managers should optimize its level and, more importantly, promote a certain way of conscientiousness that will not be harmful to entrepreneurial orientation. Instead of going beyond what is expected of them in terms of time and effort, employees should exceed expectations regarding creativity and engagement, that will result in higher levels of organizational entrepreneurship.

The study brings some contribution to the discussion on social antecedents of entrepreneurial orientation. It sheds light on possible outcomes of organizational citizenship behaviors for organizational entrepreneurship. Until now, the research in that regard was rather scarce. Moreover, study results add to ongoing discussion on dimensionality of entrepreneurial orientation. As the impact of prosocial motivation and OCB is rather similar for all three dimensions of EO, results point to rather unidimensional view of entrepreneurial orientation instead of multidimensional one.

One of the limitations is the sampling of only medium and big organizations. It was applied due to researched variables and relationships. However, it limits the research results only to those two groups. It cannot be therefore concluded that large organizations are more entrepreneurial than small ones as the latter are not represented in the sample and there are no results for their level of organizational entrepreneurship. The other limitation is the sample that is homogeneous in terms of nationality which might make the results country specific and difficult to generalize. Therefore, future empirical investigations in that notion could take into consideration bigger, international samples and/or replicating the research. 
SOCIAL ANTECEDENTS OF ENTREPRENEURIAL

Przemysław Zbierowski
Moreover, future studies might approach researched variables in slightly different manner and consider possible mediating effects of OCB and especially of prosocial motivation. Even though the direct effect of the latter one on entrepreneurial orientation has not been observed, there might exist indirect effect mediated by other variables.

\section{References}

Amabile, T.M., Barsade, S.G., Mueller, J.S., Staw, B.M. (2005), "Affect and creativity at work", Administrative Science Quarterly, Vol. 50 No. 3, pp. 367-403.

Cameron, K.S. (2008), Positive leadership. Strategies for extraordinary performance, Berrett Koehler, San Francisco.

Cameron, K.S., Dutton, J.E., Quinn, R.E. (2003), Positive organizational Scholarship. Foundations of a new discipline, Berrett-Koahler Publishers Inc., San Francisco.

Covin, J.G., Slevin, D.P. (1988), “The influence of organization structure on the utility of an entrepreneurial top management style", Journal of Management Studies, Vol. 25 No. 3, pp. 217-234.

Covin, J.G., Slevin, D.P. (1989), "Strategic management of small firms in hostile and benign environments", Strategic Management Journal, Vol. 10 No. 1, pp. 75-87.

Dess, G.G., Beard, D.W. (1984), "Dimensions of organizational rask environments", Administrative Science Quarterly, Vol. 29 No. 1, pp. 52-73.

Gebauer, J.E., Riketta, M., Broemer, P., Maio, G.R. (2008), "Pleasure and pressure based prosocial motivation: Divergent relations to subjective well-being", Journal of Research in Personality, Vol. 42 No. 2, pp. 399-420.

Glińska-Neweś, A. (2010), „Pozytywna Kultura Organizacyjna jako pożądany efekt Pozytywnego Potencjału Organizacji”, in: Stankiewicz, M.J. (Ed.), Pozytywny Potencjat Organizacji. Wstęp do użytecznej teorii zarzadzania, Wydawnictwo Dom Organizatora, Toruń, pp. 75-106.

Grant, A.M. (2007), "Relational job design and the motivation to make a prosocial difference", Academy of Management Review, Vol. 32 No. 2, pp. 393-417.

Grant, A.M. (2008), "Does intrinsic motivation fuel the prosocial fire? Motivational synergy in predicting persistence, performance, and productivity", Journal of Applied Psychology, Vol. 93 No. 1, pp. 48-58.

Grant, A.M., Berg, J.M. (2012), "Prosocial motivation at work. When, why, and how making a difference makes a difference", in: Cameron, K.S., Spreitzer, G.M. (Eds.), The Oxford Handbook of Positive Organizational Scholarship, Oxford University Press, Oxford/New York, pp. 28-44.

Grant, A.M., Berry, J. (2011), "The necessity of others is the mother of invention: Intrinsic and prosocial motivations, perspective-taking, and creativity", Academy of Management Journal, Vol. 54 No. 1, pp. 73-96.

Grant, A.M., Sumanth, J.J. (2009), "Mission possible? The performance of prosocially motivated employees depends on manager trustworthiness", Journal of Applied Psychology, Vol. 94 No. 4, pp. 927-944.

Kanfer, R. (1990), "Motivation theory and industrial/organizational psychology", in: 
Dunette, M.D., Hough, L.M. (Eds.), Handbook of industrial and organizational psychology, Consulting Psychologists Press, Palo Alto, pp. 75-170.

Khandwalla, P.N. (1977), The design of organizations, Harcourt Brace Janovich, New York.

Kreiser, P.M., Marino, L., Weaver, K.M. (2002), "Assessing the psychometric properties of the entrepreneurial orientation scale: A multi-country analysis", Entrepreneurship Theory and Practice, Vol. 26 No. 4, pp. 71-94.

Lebel, R., Patil, S. (2018), "Proactivity despite discouraging supervisors: The powerful role of prosocial motivation", The Journal Of Applied Psychology, Vol. 103 No. 7, pp. 724-737.

Lumpkin, G.T., Dess, G.G. (1996), "Clarifying the entrepreneurial orientation construct and linking it to performance", Academy of Management Journal, Vol. 21 No. 1, pp. 135-172.

Lumpkin, G.T., Dess, G.G. (2001), "Linking two dimensions of entrepreneurial orientation to firm performance: The moderating role of environment and industry life cycle", Journal of Business Venturing, Vol. 16 No. 5, pp. 429-451.

Luu, T.T. (2017), "CSR and organizational citizenship behavior for the environment in hotel industry", International Journal Of Contemporary Hospitality Management, Vol. 29 No. 11, pp. 2867-2900.

Miller, D. (1987), “The structural and environmental correlates of business strategy", Strategic Management Journal, Vol. 8 No. 1, pp. 55-76.

Miller, D., Friesen, P.H. (1982), "Innovation in conservative and entrepreneurial firms: Two models of strategic momentum", Strategic Management Journal, Vol. 3 No. 1, pp. 1-25.

Mintzberg, H. (1973), "Strategy-making in three modes", California Management Review, Vol. 16 No. 2, pp. 44-53.

Organ, D.W. (1988), Organizational citizenship behavior. The good soldier syndrome, Lexington Books, Lexington.

Palich, L.E., Bagby, D.R. (1995), "Using cognitive theory to explain entrepreneurial risktaking: Challenging conventional wisdom", Journal of Business Venturing, Vol. 10 No. 6, pp. 425-438.

Podsakoff, P.M., MacKenzie, S.B., Moorman, R.H., Fetter, R. (1990), “Transformational leader behaviors and their effects on followers' trust in leader, satisfaction, and organizational citizenship behaviors", Leadership Quarterly, Vol. 1 No. 2, pp. 107-142.

Porath, C., Macinnis, D., Folkes, V. (2010), "Witnessing incivility among employees: Effects on consumer anger and negative inferences about companies", Journal of Consumer Research, Vol. 37 No. 2, pp. 292-303.

Sharfman, M.P., Dean, J.W. (1991), "Conceptualizing and measuring the organizational environment: A multidimensional approach", Journal of Management, Vol. 17 No. 4, pp. 681-700.

Stankiewicz, M.J. (2010), „Uwarunkowania Pozytywnego Potencjału Organizacji - zarys modelu kształtowania PPO w przedsiębiorstwie (ze szczególnym uwzględnieniem przedsiębiorstw funkcjonujących w Polsce)", in: Stankiewicz, M.J. (Ed.), Pozytywny Potencjat Organizacji. Wstęp do użytecznej teorii zarządzania, Wydawnictwo Dom Organizatora, Toruń, pp. 215-239.
SOCIAL ANTECEDENTS OF ENTREPRENEURIAL

Przemysław Zbierowski 
SOCIAL

ANTECEDENTS OF ENTREPRENEURIAL

Przemysław Zbierowski
Vallerand, R.J., 1997, "Toward a hierarchical model of intrinsic and extrinsic motivation", in: Zanna, M.P. (Ed.), Advances in experimental social psychology, Academic Press, New York, pp. 271-359.

Yan, L., Yan, J. (2013), "Leadership, organizational citizenship behavior, and innovation in small business: an empirical study", Journal Of Small Business \& Entrepreneurship, Vol. 26 No. 2, pp. 183-199.

Zahra, S.A. (1993), "Environment, corporate entrepreneurship, and financial performance: A taxonomic approach", Journal of Business Venturing, Vol. 8 No. 4, pp. 319-340.

Zbierowski, P. (2012), Orientacja pozytywna organizacji wysokiej efektywności, Wolters Kluwer, Warszawa.

Zhang, Z., Wan, D., Jia, M. (2008), "Do high-performance human resource practices help corporate entrepreneurship? The mediating role of organizational citizenship behavior", Journal Of High Technology Management Research, Vol. 19 No. 2, pp. 128-138. 